\title{
Media Framing of Zanu Pf Internal Succession Struggles: Mnangagwa and the Military Factor
}

Teddy Mungwari*

Centre for Language and Communication Studies, Chinhoyi University of Technology, Zimbabwe

\begin{abstract}
This article discusses the representation of the ruling party, Zimbabwe African National Union Patriotic Front (ZANU PF) internal succession battles, particularly presidential succession. The paper argues that two factions within ZANU PF, Team Lacoste (a faction that backed Mnangagwa to succeed Mugabe) and G40 (a faction that supported Grace Mugabe to take over Presidency) fought fierce battles which the media extensively reported on. The article also argues that Grace's overwhelming ambition to succeed her husband, Robert Mugabe, led to the events where she publicly attacked Emmerson Mnangagwa until Mugabe fired him. Mnangagwa's dismissal from the post of Vice President precipitated dramatic events that led to the 'military coup' or intervention on 15 November 2017. It was widely believed that Mnangagwa enjoyed the support of the country's securocrats, who include the country's military, intelligence and the former liberation war fighters. This article further argues that the 'military coup' was a long planned strategy which began in 2008 but was brewing until it was finally triggered by the dismissal of Mnangagwa. The Zimbabwean electronic, print and social media platforms as well as foreign media actively covered the succession struggles. However, this paper only analysed the state-controlled daily, The Herald, and two daily privately owned newspapers Daily News and News Day, to examine how they framed the internal succession battles from October to December 2017. The three newspapers have diverse editorial and ideological agendas. The article concluded that The Herald, which is pro-government and ruling party, was torn-in-between Mugabe and Mnangagwa. News reporters were in a crisis on how to cover the events, especially from 13-15 November 2017, until state capture of strategic institutions by the military. However, privately owned newspapers maintained their middle of the road approach in covering the events. The paper can argue that state-controlled media's ideological and editorial policies may change to suit interests of those in power thereby compromising ethical reportage. The article also concluded that Zimbabwe's new dispensation is characterised by militarisation of state institutions with many key posts occupied by retired military personnel; which arguably may lead to manipulation of 2018 general elections. There is systematic purging of all perceived G40 members, (who are labeled as cabalists by Team Lacoste), including top civilian CIO members by Mnangagwa's administration which is allegedly guided by Military Intelligence. ZANU PF succession politics may be far from being over as G40 members might be planning a comeback - only time will tell.
\end{abstract}

Keywords: Political; Dynamic; Power

\section{Introduction}

Since the late 1990s Zimbabwean politics has been shaped by the political succession war raging within the ruling ZANU PF party. The internal fight to succeed President Robert Mugabe took dynamic changes; initially it pitted a faction led by retired General Solomon Mujuru, who was fronting his wife Joice Mujuru, against a faction led by Emmerson Mnangagwa, who was a government minister then. The succession and factional battles reached a crucial stage in 2014, when Mugabe dismissed Joice Mujuru as Vice President and purged her allies in ZANU PF and the government. Post 2014 witnessed more succession struggles between Team Lacoste and G40. Soon after 2013 general elections, two factions within ZANU PF emerged, Team Lacoste, which supported the current President Emmerson Mnangagwa, "Ngwena" (which means "crocodile"), and Generation 40 (G40), which reportedly supported Mugabe's wife, Grace Mugabe who challenged Mnangagwa to succeed Mugabe. Mungwari [1] argued elsewhere that the hope that purging Mujuru and her allies would get rid of factionalism and succession battles proved a political mirage because fresh internal struggles immediately reared their ugly heads in ZANU PF post 2014. Mnangagwa's prospects of succeeding Mugabe improved following Mujuru's exit, but evolving factional dynamics within ZANU PF, especially since the beginning of 2016 [2].

This paper contends that ZANU PF went into a sustained conflict over presidential succession, a conflict that had been brewing even since Dzikamai Mavhaire raised the issue in 1999, and exacerbated in 2004 with the Tsholotsho Declaration and the 2014 purging of Joice
Mujuru. However, it now appears that the most recent internal conflict was less a faction fight between Lacoste and G40 than a sustained purge to remove the over-weaning power of the military that had been gaining power since 2008 [3]. Whatever the speculation about whether Mugabe wanted to step down (when he was defeated by Tsvangirai in 2008 first round), or he demanded that he be protected from stepping down, the fact is that the military took charge and "won" the result of the presidential re-run of 2008. Some have called this the first coup, and even senior ZANU PF officials are candid that the military took charge and ensured the result. This result was rejected by everyone- which led to the peace treaty known as the Global Political Agreement (GPA) and the creation of the Inclusive Government (IG).

Given the foregoing revelations, ZANU PF kept the major organs of power, and the security forces refused to accept the civilian authority of the Movement of Democratic Change (MDCs). The statements of senior military officials refusing to accept the civilian authority of the

${ }^{*}$ Corresponding author: Teddy Mungwari, Senior Lecturer, Centre for Language and Communication Studies, Chinhoyi University of Technology, Zimbabwe, Tel: +263 67 22203; E-mail: teddymngwari1@gmail.com

\section{Received March 15, 2018; Accepted April 19, 2018; Published April 23, 2018}

Citation: Mungwari T (2018) Media Framing of Zanu Pf Internal Succession Struggles: Mnangagwa and the Military Factor. J Mass Communicat Journalism 8: 369. doi: 10.4172/2165-7912.1000369

Copyright: (c) 2018 Mungwari T. This is an open-access article distributed under the terms of the Creative Commons Attribution License, which permits unrestricted use, distribution, and reproduction in any medium, provided the original author and source are credited. 
part of the government occupied by the two opposition parties (MDC - T and MDC - M) are common cause [3-5].

As if this was not enough; fast events to the story of the last stages of the inevitable coup are now commonplace. First, it began with the purge of the Mujuru faction in 2014. This started with the death (or murder) of Solomon Mujuru, culminated in the expulsion of the entire Mujuru faction, and almost decimated the party. However, purging obviously opened the space for Mnangagwa and the military, and the deeper problem began to manifest itself [3].

Mungwari [5] has argued elsewhere that ZANU PF is a revolution party that devours itself. Then began the slow and relentless campaign led against Mnangagwa, and the attempt to limit the power of the military. This inevitably led to the events of November 2017, and the unfolding of a strategy that clearly was a long time in the brewing. It is very hard to believe that the events of November were a spontaneous response to the sacking of Mnangagwa and Chiwenga: the process seems far too well-organised to believe this [3]

Of significance to note are events that seemed to exacerbate the military coup. This article argues that the template that was used in 2014 in purging of Mujuru and her allies is similar in many ways to that employed in sustained attack on Mnangagwa and his allies. This article therefore draws a parallel between Mujuru purging and 2017 dismissal of Mnangagwa although the latter came back on the wave of the military. In 2014, Grace Mugabe viciously attacked Mujuru through her "nationwide campaign rallies". In 2017, Grace used ZANU PF Youth Interface rallies to relentlessly denounce Mnangagwa and his allies. This article argues that the incident of poisoned food or food poisoning at Youth Interface rally in Gwanda widened the rift between Mnangagwa and the then First Family. Mnangagwa insisted that he was poisoned by Mphoko, the other former Vice President, accused Mnangagwa of lying and undermining Mugabe on the grounds that he allegedly contradicted Mugabe's statement on the poisoning [6].

Basing on the preceding scenario, the problem for Mnangagwa was that the poisoning theory carried a lot of baggage that implicated the Mugabe family and their allies. It all started with the ice-cream theory, which implicated the Gushungo Dairies, a business owned by the Mugabes. Mnangagwa himself had to issue a press statement declaring that he had not consumed ice cream from Gushungo Dairies. However, when Mnangagwa insisted that he was indeed poisoned, which may well be true but had nothing to do with the Mugabes, the latter still felt sensitive about it. This is why Grace Mugabe was quick to respond after Mnangagwa's press statement on Thursday, 5 October 2017 evening. The Herald reported that First Lady Grace Mugabe shot down Vice President Emmerson Mnangagwa's claims that he was poisoned, arguing that he was merely seeking sympathy. She said VP Mnangagwa was "nothing" but an employee of President Mugabe. Grace Mugabe made the remarks in Harare on 5 October 2017 while launching Youth empowerment and employment creation initiatives. The Herald article was titled "First Lady blasts VP Mnangagwa". The Herald of 6 October 2017 also published articles titled "Mnangagwa clarifies poisoning statement", and "VP Mnangagwa's remarks at Mahofa's memorial in Gutu". "Press statement" by VP Mphoko was carried in The Herald of 5 October, 2017. Mnangagwa's rivals knew the effect of the poisoning theory upon the Mugabes, of which Mphoko was quick to make much out of what Mnangagwa had said at Mahofa's memorial service in Gutu.

This article argues that the food poisoning on Mnangagwa incident heightened the internal succession battle between Lacoste and G40 rivals. For Mphoko and allies, framing it as undermining Mugabe would stoke up his anger, which objective they evidently achieved. Mphoko and his allies were effectively saying to Mugabe: 'Look how he is undermining you publicly, it's time to act or you look weak " it ended whatever truththat remained between the two men. Encouraging the conflict between Mugabe and Munangagwa hastened the collapse of the latter's fortunes [7]. Magaisa further argued that it was not in G40's interest to delay the day of execution since Mugabe's demise would leave them completely vulnerable. There was some desperation to move things quicker seeing as it is Mugabe was taking his time. On the other hand, lacking the courage to challenge Mugabe (his long time boss), Munangagwa was betting on that demise happening sooner rather than later. This is presumably why he warned his rivals that the time of reckoning will be at the end. It was an ominous statement that signaled a fight back.

Mnangagwa's strategy seemed to hang on, hoping for an opening when the old father departs this universe. He lacked the courage to challenge his godfather (Mugabe) even thought it had dawned on him that he would not hand the baton to him. He was still hoping for the one last chance to present his long dossier to the politburo which he did. This was after Jonathan Moyo had presented a dossier in which he depicted Mnangagwa's state capture; therefore Mnangagwa attempted to counter the damage done.

It should be pointed out that the height of internal succession struggles finally culminated in the sacking of Emmerson Munangagwa, less than three years after his appointment as vice president of Zimbabwe, which opened a new chapter in the prolonged race to succeed long serving leader President Robert Mugabe. It had long been suggested that Mugabe was the glue that held ZANU PF together. But after purging of Mujuru and her allies and now Munangagwa and his allies, he was proving an agent of separation. While G40 had won this phase of the war, the intense battles left the party deeply wounded and divided. For Grace Mugabe, her brand of politics - aggressive, brash and disrespectful - had left her with more enemies. It was inevitable that there would be greater disintegration in ZANU PF as factions fought.

This article examined state-controlled daily, The Herald and two privately - owned dailies, Daily News and News Day. Newspaper articles from October to December 2017 were analysed in order to determine the framing of the internal succession struggles in the ruling ZANU PF.

\section{Press Representation of Factional Battles}

'Game on as ED hammers Moyo' and 'VP Mnangagwa blasts Prof Moyo' were headlines in Daily News and News Day of 13 October 2017 respectively. As alluded to in the introduction, Mnangagwa presented his long dossier to the politburo on 11 October 2017. This came as Mugabe gave Mnangagwa the floor to clear his name and respond to 'state capture' allegations leveled against him by Jonathan Moyo during the previous politburo meeting held on July 19 2017. Both papers reported that Mnangagwa and his allies 'exposed' Moyo's alleged role in leaking sensitive state secrets to the media and foreign spy agencies as part of machinations to have people to remove President Mugabe from power. But Moyo reportedly hit back claiming Mnangagwa was, among other things, behind the Tsholotsho Declaration which Mugabe viewed as an attempted coup plot. This article argues that the deeply divided ruling party's ugly tribal and succession wars were far from over that time. Mnangagwa's combative dossier indicated that Mugabe had no reason to fear a coup against him - blaming Moyo for raising false 
alarms in his alleged desperate bid to destabilize the country's security sector. Moyo had earlier alleged that Mnangagwa had captured key state institutions including the military in his bid to succeed Mugabe (Daily News, 14 October, 2017: 'Split ZANU PF now in flames'). What is interesting to note is that Jonathan Moyo had warned in a July 2016 letter to Mugabe that a coup was being mooted against him by army generals.

It also emerged that Mnangagwa reminded Mugabe in the politburo that when most ZANU PF officials had accepted Mugabe's stunning defeat to opposition leader Morgan Tsvangirai in the hotly disputed 2008 polls, it was him and the country's securocrats who had rescued him and the ruling party from being dethroned from power (See also Knox Chitiyo 2009: "The case for security sector reform in Zimbabwe").

Chitiyo [4] posts that the post-2000 formalization of the alliance between ZANU PF and the security sector was designed to prevent MDCs access to the levers of state power. The MDC's popularity as evidenced in general and presidential elections in 2000, 2002, 2005 and 2008, was a major threat to ZANU PF's hegemony. From 2000 until the establishment of the GNU in 2009, politics in Zimbabwe was dominated by military exigencies. This paper contends that military operations and the militarization of institutions was characteristic from 2000 and has been documented by political analysts [8-12].

It can be argued that during the period 2014 to 2017 the military seemed in control of levers of power through the capture of state institutions in support of Mnangagwa's faction; which inevitably led to the November 2017 coup; which the military denies was not military takeover but intervention to avoid political, social and economic crisis which 'could have ended in violent conflict'. Important to note is that when Grace Mugabe had a public attack on Mnangagwa in October 2017, she accused some army elements of plotting a coup. Mugabe had also categorically ordered the military to 'steer clear of politics' but stay in barracks, Mungwari [5] article titled: 'Framing of ZANU PF purges and Succession Dynamics'). President Mugabe had also earlier in 2015 told the security chiefs not to interfere in politics; and Grace Mugabe had told the military to shoot her which she declared she did not care or fear. This article therefore argues that the rift between the First Family and the military had long been widening, consequently the November events were not so much a surprise.

\section{Grace Mugabe's Ambition for VP Post}

The following stories in Daily News were analyzed: 'Bigwigs panic over ZANU PF congress ... as they fear circus of long knives ', 'ZANU PF wars will end badly ... Mutasa warns Mugabe, brawling aids', 'War Veterans Oppose December Congress', 'ED set to go down fighting,', Grace leads race for VP...Muchinguri, Madzongwe are dark horses,' 'ZANUPF youths backing Grace ... Grace describes Mnangagwa as a cancer,' 'Team Lacoste hatches plan B ... Pushing Muchinguri - Kashiri for VP,' 'Woman VP a wish list - Mnangagwa,' 'It is sink or swim for Mnangagwa.. as VP is challenged to fight back in succession war', 'Grace must not run for VP','Plot to oust ED thickens: as Grace's allies push for her promotion', 'Extraordinary ZANU PF congress a G 40 event', 'Grace's rally splits churches', 'Let's crush ED - Grace,' 'Grace humiliated, booed ': 16, 17, 19, 20, 21,22,24,30, 31 October 2017; 2, 4, 4, 6, 5-11 November 2017 respectively.

News Day published the following articles:

'Grace for president', 'Grace takes charge of ZANU PF congress', 'War veterans declare war against G40,' 'war veterans vow to thwart G40 at ZANU PF congress', 'Zanu PF youths fight over Grace', 'Cartoon: Grace takes charge of ZANU PF congress', 'Rebel war vets faction warns of civil unrest', 'Prepare for Armageddon-Mnangagwa warned', 'Grace dates Vapostori', 'Will ZANU PF in-fighting end cult politics, heroworshipping?, 'Team Lacoste guns for Mugabe,' 'Cartoon,' 'ZANU PF suspends four top Mnangagwa allies,' 'ZANU PF congress preps up in smoke', 'War veterans plot ZANU PF split', 'Tribal dimension in ZANU PF succession poses danger to nation', 'Mnangagwa allies cry foul ', 'Chipanga can go hang : war vets', 'Cartoon': 16,17,17,18,19,19,2 $3,25,25,27,27,28,31,21,30,30,30$ : October 2017, respectively.

\section{The Herald carried the following stories:}

'First lady blasts VP Mnangagwa', 6 October 2017,'President lights up city of Kings', 'First lady calls for action on ED', 'Was I wrong on VP Mnangagwa?' 'I hear you on female VP,' The Sunday Mail 5 November 2017, 'Mnangagwa must go - First Lady', 'President blasts divisive elements' , 'Thousands meet First Lady ... Mnangagwa harboring coup plots,' 'Will stand by the president,' and 'Masvingo probes Byo interface booing,': 6 November 2017 respectively. It is important to note that The Herald covered fewer stories because it deliberately omitted some because of editorial polices.

It is significant to point out that the decision to cancel the Annual Conference in December and replace it with a special congress had escalated the deadly battle for the control of the party and its structures in the former liberation movement. There was gnashing of teeth particularly among senior officials linked to Team Lacoste, as fears were abound that this special congress was targeting Mnangagwa. Daily News of 16 October 2017 quoted a ZANU PF central committee member saying: The fear of a new circus of long knives [after the disputed 2014 'elective congress' which ousted former Vice President Joice Mujuru from office] is more so as the G 40 is behind this move", and is also receiving its calls for an amendment of the party's constitution to reintroduce a clause that compels the party to have a woman in the presidium.

ZANU PF resorted to the quota system in 2014 to accommodate Mujuru at the expense of Mnangagwa. However, the system expediently abandoned it in 2014 to allow him to succeed Mujuru. The move to amend ZANU PF's constitution to re-introduce a clause to have a woman in the party's presidium was originally as a women's league resolution at the annual conference that was held in Victoria Falls in December 2015 [5].

News Day of 16 October 2017 also reported that ZANU PF Manical and provincial executive committee '....made a strange demand that the agenda for the party's proposed extraordinary congress includes the appointment of a female vice president in a suspected bid to smuggle First Lady Grace Mugabe into the presidium '. This paper argues that once one province proposes an idea which suits the First Family (then) the rest of other provinces normally endorsed the same issue immediately. However, Masvingo and Midlands provinces were odd because of their open support of Mnangagwa.

News Day of 17 October carried a story titled 'Grace takes charge of ZANU PF congress' while Daily News of same day covered a story with a headline 'ZANU PF wars will end badly ... Mutasa warms Mugabe, brawling aides'. This article argues that Mugabe had now taken side to belong to G40 faction, evidenced by his setting up a steering committee, comprising mainly of Grace's allies, to organize the congress. Of particular interest to note was that Major Douglas Nyikayaramba was among the committee members yet most of the top securocrats belonged to Team Lacoste which backed Mnangagwa. 
Cartooning succession politics was extensively captured during 2014 purging of Mujuru. News Day of 19 and 27 October 2017 made a caricature of Mnangagwa. In the first cartoon, Mnangagwa is depicted tied and bound by ropes, wincing in pain due to the "heat" from congress Dec-2017; the caption on the cartoon reads: "Grace takes charge of ZANU PF congress." Part of the cartoon shows Grace holding a spiked knobkerrie to strike if Mnangagwa survives the heat from the pot. The other ominous cartoon (which totally resembles the cartoon that portrayed Mujuru published by The Standard of November 1622 , 2014) depicted Mugabe driving a commuter omnibus going to December extraordinary congress, with him menacingly holding a lethal knobkerrie with spikes, and looking through the window; perilously and desperately hanging on the same omnibus is Mnangagwa defying all odds. Grace Mugabe inside the same bus is laughing at Mnangagwa's precarious situation [1] $\mathrm{PhD}$ thesis for more details on succession politics cartooning).

Of importance to point out is that as ZANU PF succession wars reached a deadly climax, former state security minister Didymus Mutasa - who was for decades one of Mugabe's closest confidants warned that things could end up very badly for his boss, the ruling party and the country as a whole if they were not carefully managed . Mutasa was sacked from ZANU PF together with former vice President Joice Mujuru and other liberation war stalwarts, in the run-up to the party's hotly-disputed 2014 congress, on unattested charges of plotting to unseat Mugabe.

Daily News of 17 October 2017 also quotes war veterans loyal to Emmerson Mnangagwa who argued that there was no need for a special December congress for ZANU PF, and said Mugabe must rein in his wife. Zimbabwe National Liberation War Veterans Association (ZNLWA) secretary general Victor Matemadanda, whose executive had already endorsed Mnangagwa as President, said war veterans aligned Mnangagwa had all the audacity and temerity to challenge the First Family, showing again that the ruling party's succession struggles needed a closure for the development of the country and restore peace in the former liberation movement. The relationship between Mugabe and war veterans broke in 2016 when Mugabe decided to sideline the vanguards in favour of Youth League and Women's League; this resulted in two different camps of former fighters, that is, Chris Mutsvangwa and Mandi Chimene camps, although the constitution recognizes the former's camp yet the First Family preferred the latter camp.

However, one of the three critical wings of the ruling party, the ZANU PF youth league - declared its undying support for First lady Grace Mugabe to take over vice presidency from Emmerson Mnangagwa, whom it described as a cancer. The declaration by the youth league's Manicaland chair, Mabuso Chinguo came two months before a decisive extraordinary congress where ZANU PF would amend its constitution to accommodate a woman for Vice President and second secretary of the party. Nonetheless, Team Lacoste hatched plan B where it pushed Muchinguri - Kashiri for Vice President in case their trump card in the succession race, Emmerson Mnangagwa was jettisoned from his position through the planned amendments to the party's constitution. In the meantime, Mnangagwa was set to go down fighting as his loyalists planned to make their last stand at the special congress.

One of the arguments of this article is that ZANU PF has over the years used various apostolic sects for support from the period its hegemony was waning. During the ZANU PF succession battles, Grace Mugabe sought support from the same sects churches. ' Grace dates
Vapostori " "Grace Rally splitschurches". The apostolic sect has been ZANU PF's favourite hunting ground. In the run up to any important election, ZANU PF politicians are known for trooping to church services convened by various seats to win their hearts and minds. One of the most enduring images remain that of President Robert Mugabe, beamed on National Television in 2010 donning a white garment holding a sacred stuff (knobkerrie) at a Johanne Marange Shrine. Grace Mugabe did the same by wearing complete garments; regalia for apostolic sect women: this might be interpreted as blasphemous in religious circles because such regalia are 'holy' and sacred. ZANU PF's affinity for the sect resulted in church leaders falling over each other to ingratiate themselves with the party's leadership.

Politicians were stampeding to organize Grace rally, with ZANU PF's Harare provincial political commissar Shadreck Mashayamombe inviting churches to the rally, while the Minister of Sport, Recreation, Arts and Culture, Makhosini Hlongwane hadalso been inviting churches to the same event.

Daily News of 6 November 2017, carried a story with a headline 'Lets crush ED - Grace.' Hardly a day after Mugabe and Grace, his wife, attacked Mnangagwa for alleged fomenting divisions in ZANU PF, Grace savaged Emmerson Mnangagwa again. In her address to thousand of apostolic church members in Harare, Grace described Mnangagwa as "a snake" whose head must be crushed. Grace Mugabe implored on ZANU PF supporters to 'finish off' the vice president, claiming he had harbored ambitions to grab power from Mugabe from as far back as 1980. Daily News quotes Grace Mugabe: Makhosini (Hlongwane), that man is a liquidator, ravisher, he is dangerous that person and you can see his envious look at the president. He is so jealous that he can even kill someone. Since 1980 there were a lot of things that happened that we know and you ought to know as Zimbabweans. In 1980, this person called Mnangagwa wanted to stage a coup to grab power ... Let me tell you (that) after the 1980 elections he told the president that"there were whites who wanted to kill you so you and (Maurice) Nyagumbo and (Enos) Nkala should skip the country immediately to Mozambique. When the president told Samora Machel upon arrival he was ordered back but when he called Mnangagwa to tell him that he wanted to come back, Mnangagwa told him not to return because he wanted to stage a coup. So this person has always wanted to take over power through illegal means (Daily News, The Herald, and News Day 6 November 2017: 'Thousands meet first lady...', 'Mnangagwa harboring coup plots'; 'Mnangagwa out - Grace,' respectively).

Considering the foregoing revelations by Grace, this article argues that Mnangagwa had always harbored to stage a coup to wrestle power from Mugabe. It would seem Mnangagwa waited for an opportunity which inevitably presented itself after he was fired. This article further argues that Graces speech, when she addressed the apostolic sect members, was charged with absolute anger, allegedly because she was humiliated and booed during her speech at the ZANU PF youth interface rally held in Bulawayo,(Zimbabwe's second biggest city).

At the Bulawayo youth interface there were choruses of disapproval at Grace's audience. Seemingly unmoved by the chants Grace declared:

Even if you don't want to listen it's up to you, I will keep on telling you reality on the ground. If you have been paid to boo me continue but I will say it. I don't care and I will stand for the truth. Bring soldiers and shoot me, I will continue saying the same things. I will never be stopped. Boo, go ahead, do it I don't care, I am powerful - I stand on my own.

Grace took revenge by twisting the knife into Mnangagwa, accusing 
the politician of insubordination. It should be noted that the former guerilla leader (Mugabe) was annoyed by the show of disrespect by the faction aligned to Mnangagwa (Team Lacoste). Mugabe said that since he was the one who appointed Mnangagwa to the position of Vice President in 2014 he could also by the same token remove him.

Why do they insult me in Mnangagwa's name; did I do wrong in appointing Mnangagwa as my deputy? If I did then I will remove him as early as tomorrow ... We cannot continue being quiet when we hear that up until today, there are still people in Masvingo who are saying that this province is not Mugabe's but Mnangagwa's. In Midlands, it is the same story. 'But we hear it is a small group (fanning trouble) and these people are insulting the president everyday, but we have our people who follow the party's principles and they want unity.'

I argue in this article that the ZANU PF youth interface in Bulawayo was the climax of succession and factional battles in the former liberation movement. The issue of tribal overtones also exacerbated the succession matrix dynamics but one center of power was another factor in power struggles. Robert Mugabe asked an ominous question: "was I wrong on VP Mnangagwa?" The relationship between Mugabe and Mnangagwa had reached breaking point.

"Mnangagwa must go- First Lady" was the headline in The Herald of 6 November 2017. The state controlled daily newspaper reported that Grace Mugabe said Vice President Emmerson Mnangagwa and his lieutenants accused of fanning divisions within ZANU PF, must be expelled before the party's Extraordinary Congress to be held in December 2017. Addressing members of indigenous apostolic sect during the "Super Sunday" rally in Harare on 5 November 2017, the First Lady said those who were pushing the "Team Lacoste" agenda should be fired before the Special Congress to cleanse the ruling party of factions. Grace said that before the start of the Extraordinary Congress, all the party office bearers should stepdown except the President who had since been endorsed as the party's first Secretary and candidate for 2018 elections "we are all going to step down except for the president who has since been endorsed. Some will get positions while others will lose them. Those who lose their posts will go into farming..."

The article contends that following the foregoing threats to expel Mnangagwa, the nation was gripped by tension and anxiety. Succession battles had reached the boiling point and the worst was foreboding.

\section{The Fall of Mnangagwa}

'Mugabe fires Mnangagwa' was the headline in News Day of November 7, 2017. The newspaper's lead paragraph captured it all: President Robert Mugabe yesterday dropped the bombshell on his deputy and personal assistant, Emmerson Mnangagwa, axing him from government for allegedly, "consistently and persistently exhibiting traits of disloyalty, disrespect, deceitfulness and unreliability."

Mnangagwa's expulsion came exactly 48 hours after Mugabe fired warning shots at a ZANU PF Youth interface rally in Bulawayo, and three years after the VP's predecessor Joice Mujuru was fired from the same post in 2014 on similar allegations.

The Herald of 7 November, 2017's headline read: 'VP Mnangagwa fired from Govt' ...'First Lady for VP: Provinces'- these two stories were juxtaposed. The dismissal was announced by the Minister of Information, Media and Broadcasting Services, Ambassador Simon Khaya Moyo, at a press conference at his Munhumutapa offices in Harare. Khaya Moyo quoted a section of the constitution and as part of allegations levelled against Mnangagwa he added "He has also demonstrated little probity in the execution of his duties".
In the other story, the ZANU PF leadership in various provinces joined calls for the elevation of First Lady Grace Mugabe to be one of the party's two vice presidents. The provinces also recommended the expulsion of Vice President Emmerson Mnangagwa and several party members for undermining President Mugabe's authority. I have argued elsewhere that ZANU PF was a liberation party that was devouring its own. Characteristically with ZANU PF structures and wings, nearly all provinces called for Mnangagwa ouster in one unison.

The Herald of 8 November 2017 published a story with a headline: '9/10 provinces backed ED sacking'; 'ZANU PF expels Mnangagwa' was the headline of a story in The Herald of 9 November 2017. 'Mnangagwa goes into hiding' was the headline of a story in News Day, November 8 , 2017; and 'Mnangagwa flees into exile' read the headline of Daily News, November 92017.

Nine of ZANU PF's 10 provinces endorsed the sacking of former vice President Emmerson Mnangagwa, while Midlands was expected to join other provinces. Following party structures, ZANU PF expelled Mnangagwa two days after Mugabe dismissed him from Government. It should be pointed out that the sacking of Emmerson Mnangagwa less than three years after his appointment as vice president of Zimbabwe opened a new chapter in the prolonged race to succeed long serving leader, President Robert Mugabe. The problem of factionalism has long been recognized in politics. Factions arise because people tend to align with groups whose interests they identify with new factions may arise which out compete and vanquish old fashions producing a creative destruction phenomenon within the political party. It is in this context that it may be argued that the factional wars in ZANU PF may be viewed, at least in theory, as no more than a process in which the old is collapsing while the new is taking over [6].

When Mnangagwa was fired by Mugabe, he fled into exile and the media extensively covered the drama. However, what is critical to note is that Mnangagwa vowed to take Mugabe head-on. Daily News and News Day of 9 November carried the following headlines respectively: 'Mnangagwa flees into exile... and vows to take Mugabe head-on', 'Mugabe out in weeks - Mnangagwa.' Another story in News Day on same day read: 'End of era, dismissal of Mnangagwa'. Both newspapers reported on the ominous vow by Mnangagwa that he would come back and dislodge President Robert Mugabe from both ZANU PF and government in the next few weeks. In the statement from his new base in South Africa after skipping the country via Mozambique on 7 November 2017; Mnangagwa for the first time openly challenged Mugabe and Grace, saying they were 'resident in the past' and hindering the progress of Zimbabwe.

\section{News Day quotes Mnangagwa asserting:}

I will go nowhere 1 will fight tooth and nail against those making a mockery of ZANU PF's founding principles, ethics and values...You (Mugabe) and your cohorts will, instead, leave ZANU PF by the will of the people and this; we will do it in the coming weeks as Zimbabweans in general now require new and progress leadership that is not resident in the past and refuses to accept change. ...As 1 leave post (VP) for now, I encourage all loyal members of the party to remain in the party, to register vote, as we will, very soon, control the levers of power in our beautiful country and party, 1 will be communicating with you soon and shall return to Zimbabwe to lead you.

Mnangagwa did not specify how he intended to achieve the change. This article argues that Zimbabwean politics had entered another phase (End of Era). 
Following exiled former Vice President Mnangagwa's chilling threats; the ZANU PF government said it had put its security system on high alert to thwart any rebellion. The South African government said it was not expecting a coup but was nevertheless watching its troubled neighbor closely for any signs of instability (Daily News, November $10,2017)$. One interesting issue in ZANU PF is that any one allegedly aligned to Mnangagwa was targeted to be purged; the same way when Mujuru was fired in 2014 and her perceived allies were purged as well. However, some of Mnangagwa allies were reportedly said to have dumped his camp (Lacoste) to save their political scheme after Mugabe gave the greenlight for the massive purge. The rhetoric of calling for "unity" becomes a cliché because ZANU PF's succession and factional wars had become synonymous with unending purges.

This article contributes towards understanding of how the army takeover was executed in the ZANU PF succession war. From South Africa Mnangagwa went to China at a time when General Chiwenga was also in China. Mugabe and his civilian CIO had planned to arrest Chiwenga on his return but as this article illustrates, the army General had been informed about it already. Chiwenga survived an attempted arrest by Zimbabwe Republic Police Support Unit on his arrival from China at the Robert Mugabe International Airport. This article argues that this airport incident triggered a chain of events which led to the military effecting what has been termed a 'soft coup'. The arrest was part of a plan to weed out former vice president Emmerson Mnangagwa's top allies. A team was deployed to arrest him, but Chiwenga had been informed of the plot by the military intelligence. Chiwenga then held a press conference at the army's KGVI headquarters (now renamed as Josiah Magama Tongogara Barracks), warning the military could "step in" to avert a potential crisis caused by infighting in ZANU PF.

'Chiwenga warns Mugabe, ZANU PF... as military rebukes ruling party over its infighting': 'Chiwenga calls Mugabe to order...Demands end to ZANU PF purges'- these were headlines of stories in Daily News and News Day of November 14, 2017 respectively. Both newspapers reported that the Zimbabwe Defence Forces (ZDF) called President Robert Mugabe to order and directed him to immediately stop the ongoing purges on former Vice President Mnangagwa's allies ahead of ZANU PF's extraordinary congress in December. ZDF Commander General Constantino Chiwenga told journalist at the army's KGV1 headquarters in Harare that the threat to the nation and ZANU PF by "counter-revolutionaries" in the ruling party could force the army to "step-in". Chiwenga made four key demands that Mugabe should urgently fulfill, failure which the army could "step-in", which were: to stop reckless utterances by politicians from the ruling party denigrating the military which is causing alarm and despondency within the rank and file; that the current purging of which is clearly targeting members with the party with a liberation background must stop forthwith; that the known counter-revolutionaries elements who have fomented the current instability in the party must be exposed and fished out; and as the party goes for the extraordinary congress members must go with equal opportunity, to exercise their democratic rights.

At the press briefing, defiant Chiwenga who was flanked by Zimbabwe National Army Commander; Lieutenant General Philip Valerio Sibanda, Air Marshall Arson Moyo, army chief of staff (administration) Major General Douglas Nyikayaramba, over 90 major generals, brigadier generals, wing commanders and senior army commanders raised concern about the dismissal of Mnangagwa and other senior party officials with liberation war credentials.

However, on 14 November ZANU PF youth leader Kudzanai Chipanga also held a press conference where he attacked Chiwenga, labeling him a "rebel" and "criminal" who should be held accountable for the Marange diamonds. As if to exacerbate and foment the succession and factional battles, ZANU PF youth league leapt to Mugabe's defense, telling Chiwenga that he had no authority to determine who leads Zimbabwe. ZANU PF youth league secretary Kudzanai Chipanga, in reaction to Chiwenga's unprecedented public reprimand of Mugabe over the handling of succession debate in ZANU PF - said the army general had gone rogue; and that as youths, "they were prepared to shed blood defending Mugabe".

Also in a statement of 14 November, ZANU PF spokesperson Khaya Moyo described Chiwenga's remarks as "an outrageous initiation of professional soldiership"...Clearly calculated to disturb national peace and stability, the said statement by General Chiwenga was not signed, and which did not represent the rest of the command element, suggests treasonable conduct on his part as this was meant to incite insurrection and violent challenge to the constitutional order: Indeed, this is what happens when the gun seeks to overreach by dictating to politics and norms of constitutionality".

As a result, Mugabe drew battle lines with his security chiefs that he declared that he would not succumb to ZDF Commander General Chiwenga's threats to "step-in" and restore order in ruling ZANU PF party (News Day: 'Chiwenga, Mugabe face-off; 'Zimbabwe on the edge... as tension- filled country enters uncharted waters' - Daily News, November 15 2017). This article argues that the military's unprecedented stance to warn Mugabe and his waring party had reached a point of no return.

The military responded by moving equipment including tanks into Harare after which it secured strategic places such as the Munhumutapa Building, which houses the President and his deputies' offices, Supreme Court, Parliament and ZBC. The army advanced to Mugabe's residence around $10.30 \mathrm{pm}$ on 14 November night before descending on key G40 faction members between 2 am and 2.30 am on 15 November morning. A number of arrests were executed on Ignatius Chombo and Chipanga but Saviour Kasukuwere and Jonathan Moyo survived a fierce shootout and later sought refuge at Mugabe's house in Borrowdale. The military also raided Chikurubi Support Unit base where they took control of the police armory.

By 3 am on 15 November 2017, the army had secured all vital locations prompting Major-General Sibusisi Moyo to announce an hour later that the army had stepped in to defuse a potential crisis. $\mathrm{He}$ insisted that the army had not effected a coup and would not harm Mugabe.

'ZANU PF unfazed by Chiwenga'; 'Army arrests G40 'criminals"; 'Mugabe under house arrest' were headlines of stories in The Herald, News Day and Daily News, November 162017 respectively. After surviving so many challenges from courageous opponents, it was his former allies who in the end administered the final assault. It was a coup in all but name. The soldiers effectively took control of the Zimbabwean state. The military placed Robert Mugabe under house arrest following their seizure of power in the early hours of 15 November 2017. This marked the end of an era-Mugabe had ruled for 37 years.The military kept him on to enable their elder statesman a dignified exit. However, it can be argued that the demise of Mugabe's rule will not be mourned but celebrated. This celebration is not because Zimbabweans prefer military rule. It simply demonstrates how Mugabe's long rule had become almost universally despised, even within his own party, despite appearance to the contrary [13]. His rule generated many opponents both at home and abroad. But no one seemed to have a clue on how 
to get rid of him. The opposition had tried everything, to no avail. The majority of the Zimbabweans were despondent and frustrated. For many he simply had to go, by any means necessary.

Magaisa [14] further reckoned that the last straw for most people within and outside ZANU PF was the increasingly evident possibility that Mugabe's wife, Grace Mugabe was well on course to succeed him. That would have created a Mugabe dynasty. Many found the Mugabe dynasty extremely repulsive. There might have been a residue of sympathy for Mugabe but many are repulsed by Grace Mugabe's brand of politics. She was brash and condescending, with a penchant for humiliating adults in public. Many dreaded the prospect of her Presidency. Another factor that made Grace Mugabe highly unpopular was her arrogance, greed and willingness to publicly defend allies who were accused of corruption. She was not shy to show her power, although she was repeatedly warned that it was borrowed power, the strength of which depended upon her husband. She had taken to a tendency to grab whatever assets she wanted and to do as she pleased. The habit of accumulation profligacy by her family irked many Zimbabweans struggling to make ends meet.

But it was standing in the way of Emmerson Mnangagwa's ambitions that proved to be her undoing. After waiting in the wings for nearly three decades and a heavy investment in loyalty to Mugabe, arguably Mnangagwa's exit was humiliating and embarrassing particularly because it was authored by Grace Mugabe and allies. Jonathan Moyo in particular was a perennial thorn in the flesh, with social media to harangue Mnangagwa. It was the sacking of Mnangagwa and the threat to purge members of his faction from ZANU PF that proved to be the straw that broke the Camel's back.

At that point, the Lacoste faction, as Mnangagwa's faction was known, chose to activate the nuclear option, by drawing on its alliance with the military. It had always been suggested that Mnangagwa's strength lay in association with the military. In the end, it was the military that came to his defense and as events show, confirming that his power lay in the military [14].

Perhaps Mugabe's greatest mistake was that power got to his head so much that he forgot where it came from 2000. It was not the people that had kept him in power in his twilight years but the might of the military (as evidenced from 2008 elections) when his presidency was in jeopardy after losing to Morgan Tsvangirai in the first round.

It is crucial to any understanding of the current crisis to recognize the growth of the securocrates state. Mandaza [8] described in considerable detail in his analysis of the "securocrate state"- which deals with the process of military capture of the state in the past decade; arguably from the year 2000 to present (2018). Chitiyo [4] also asserts that from 2000, politics in Zimbabwe was dominated by military exigencies. This article therefore argues that the military coup on November 15, 2017 was not a surprise, as rhetoric by securocrates that they are the stockholders of ZANU PF meant one day they seize power. In this regard the analysis by Ibbo Mandaza [8] of the "securocrate state" in fact is almost prophetic about the state of affairs in Zimbabwe, and, in particular, the outlining of the growth of a securocrate state, the capture of state institutions, the increased centralised power under the presidency and the manner in which the security sector has become indispensable to maintenance of power [9-11].

Important to note is that the new men in charge of Zimbabwe were keen to insist that this was not a military takeover. It did not diminish the fact that it was. They were merely choosing their words carefully because they knew a coup is a hard sell to the region (SADC and AU) and the rest of the world.

This paper argues that the military had long planned the coup in order to hand over power to Mnangagwa; therefore when he was fired and fled the country Mnangagwa's ominous threat that he would come back in few weeks to take the levers of power could not have been a coincidence. It was going to be a glorious returnfor Mnangagwa after what seemed to be the end of a long career - coming back to lead ZANU $\mathrm{PF}$ and Zimbabwe. However, Mnangagwa and the military must know that like Mugabe, they have created a monster that could haunt them in future. History shows that once the military has tasted power; it will develop an appetite for more of the same in future. The current general, will vacate office to assume political power (through retirement), but from now on they must always watch their backs because they have shown their subordinates the possibilities that the gun avails [14].

Indeed Zimbabwe is undergoing transition. Tables seem to have turned. As for G40 their fortunes have dipped in dramatic fashion. There were lessons from history, such as the fate that befell Jiang Qing, the wife of Chairman Mao and her allies known as the Gang of Four. They will now be at the mercy of the new military authorities. When Mugabe and Grace were under the house arrest, cabinet ministers and ZANU PF officials, such as Jonathan Moyo, Ignatius Chombo, Savior Kasukuwere, Kudzanai Chipanga among others were detained by the army which had taken charge of the country's affairs. The military who "stepped-in" claim they were concerned in "flushing out" G40 'criminals' surrounding President Robert Mugabe. However, this article questions the selective target of G40 members only yet there are many officials in Team Lacoste allegedly involved in high corruption such as Obriel Mpofu, top military officials and Mnangagwa himself.

It should be pointed out that state-controlled media was in a crisis on how to report events from the day the military coup occurred on 15 November 2017. When The Herald on November 15 published a story titled 'ZANU PF unfazed by Chiwenga....raps him for treasonous statements, reaffirming primary of politics over gun'; the military immediately gave an urgent order for The Herald to publish another edition of newspaper same day. Such a scenario only confirms that news reporters in state-controlled media dance to the tune of who calls the piper-there are no permanent loyalties in politics in as much as there are no permanent friends or enemies but permanent interests.

The media's agenda was to continue covering the state of affairs in Zimbabwe. The Herald of 17 and 18 November, 2017 carried stories with the following headlines: 'President, Gen Chiwenga meet', ' 8 provinces want President to quit'; Daily News of 17 November published stories titled: 'Dawn of new era! ...as Mugabe, Chiwenga meet','Mnangagwa now back in Zimbabwe,' 'More Mugabe allies arrested; 18 November; 'Mugabe cornered', 'Mugabe allies go into hibernation'; 'Anxious Zimbos find humor in political crisis'; News Day of 17 November published a story with a headline 'Mugabe, Chiwenga in cliff hanger talks'.

Important to note is that Zimbabwe's "coup" is a class of its own. Its authors have been keen to downplay it, insisting that it is not a coup but "military intervention to save a crisis". Most Zimbabweans regardless of their political orientation reacted positively to the military intervention, seeing it as a necessary evil to get rid of Mugabe's 37 year old rule which has left them pauperized. There is desperation for change -any change will do, as long as it is not Mugabe. People just wanted Mugabe to go. Ironically, the opposition which has fought ZANU PF since 1999 were comfortable with military coup- was this not betrayal of the electorate? For the opposition; was Mugabe the person, the 
stumbling block to Zimbabwe's problems or it is the system ZANU PF? Removing Mugabe seemed not an easy task, hence negotiations with him to step down.

In this regard, South Africa President Jacob Zuma, in his capacity as chairman of the Southern African Development Community (SADC), he dispatched a special envoy to mediate dialogue between Chiwenga and Mugabe. As negotiations dragged on, Mnangagwa who had left the country had come back in the country as he had promised two weeks earlier. Mnangagwa knew the legal complications before he could take over. The operation to remove Mugabe hit a rock for a while. After taking the bold step to seize power, the military generals were also reluctant to go the full mile. The generals said they were merely removing "criminal elements" who were around Mugabe. The reason for the Military's reluctant approach is that they knew a coup would be illegal and would not be accepted by the community of nations, particularly in Africa. The resulting regime would not have legitimacy. Predictably, the Africa Union (AU) made it clear that it would not respect any constitutional change of government. The regional body, SADC convened an urgent meeting and issued a cautionary statement. The disclaimer by the military was obviously intended to pre-empt these concerns. Mugabe was aware of the legal complications that is why he kept digging in.

Although there were several routes to constitutionally remove Mugabe, removal of president by impeachment seemed a better option. This process of removing the president is conducted by parliament. The option was always available even before the military intervention, but would have been impossible as long as G40 was still active. ZANU PF had to also use provincial structures for the president to quit. Nonetheless, Mugabe for a while remained arrogant as he disregarded ZANU PF declaring that he was going nowhere (Daily News, November $20,2017)$. In a televised address, beamed live on national television, Mugabe noted the fast-paced events of the past few days, including internal processes activated by his ZANU PF party to get him out of office, but gave no hint that he was considering vacating the presidency anytime soon. According to press reports that even though his party had taken the decision to recall him on 19 November, replacing him with Emmerson Mnangagwa though central committee meeting, Mugabe declared he would preside over the ruling party's congress which was due in two weeks, ignoring the fact that he was no longer the leader of ZANU PF.

The nation had been made to wait for his address that had been scheduled to be aired before prime time news at $8 \mathrm{pm}$ on state television, but after nearly two hours of waiting, the Zimbabwe Television (ZTV) crew later beamed a downcast Mugabe, the presence of security chiefs, ready to go live with his address; now humorously called "Asante Sana" speech by Zimbabweans. Mugabe spoke incoherently constantly shuffling papers, said he still had a role to play in ZANU PF and had heeded the military decisions to end the bitter factional squabbles in his party. He said Zimbabweans, who demonstrated against his unpopular rule in their tens of thousands in Harare and Bulawayo on 18 November 2017, are peaceful and pleaded for engagement to "resolve our differences".

The congress is due in a few weeks from now and I will preside over it, it must not be predetermined by any act calculated to undermine it or to compromise it. I am aware that many developments have been taking place in the party by individuals in the name of the party, given the failings of the party.... However, we cannot be guided by bitterness ad revengefulness, which would not make us any better... Zimbabweans... We must learn to forget and resolve our issues in a comradely Zimbabwean way, I am confident that from tonight that our nation will get focused as we put shoulder to the wheel...

This article notes that Mugabe's speech was an anti-climax to the entire world's expectation in general, and Zimbabweans in particular. As for the security chiefs, they may have been shocked with disbelief. That was Robert Mugabe the Machiavellian at it again! However, parliament was waiting to impeach Mugabe on 21 November 2017, if he did not resign to relinquish power.

\section{The Downfall of Robert Mugabe}

This article argued earlier that even as his old military and political allies applied pressure upon him, Mugabe refused to bend. His anti-climactic "Asante Sana" speech on 19 November 2017, will be remembered as the most deflating moment of those riveting and suspenseful days in November. That Sunday evening, the world waited with anxiety as Mugabe prepared to deliver what most believed would be his resignation speech (Daily News, November 20,2017: 'Arrogant Mugabe disregards ZANU PF'). What is striking with the Daily News headline story is that it was juxtaposed with another story on the same page which was titled '.. as ED takes over ZANU PF'. This meant that although Mugabe disregarded ZANU PF, Emmerson Dambudzo Mnangagwa was taking over ZANU PF.

Twenty-four hours earlier, Zimbabweans from all walks of life had marched peacefully in Harare and Bulawayo calling on him to step down. It was a big festival where the entire nation exhaled. A few hours before the much-anticipated speech, Mugabe's party had sacked him. ZANU PF had also given him an ultimatum to resign by midday the following day or face impeachment (Daily News, November 20, 2017: "Party to impeach Mugabe tomorrow"). There was so much anticipation that global news networks suspended normal programming to capture the historic moment of Mugabe's resignation. It never came. Instead, Mugabe rambled on with visibly uncomfortable generals by his side. The generals were asking him to leave with dignity but he was intransigent. He was not going to leave without a fight.

The Herald of 21 November, 2017 carried two stories titled 'Cabinet meets at State House today' and 'President ED bury the hatchet'; while Daily News, November 21,2017 published a story with a headline 'Parly in move to kick out Mugabe.. as Zambia dispatches Kaunda to Harare' and another story titled 'Mugabe to engage Mnangagwa'.

It should be noted that Mugabe only relented on 21 November when it became clear that parliament was going to impeach him. On the morning of his resignation, he had even called a cabinet meeting as if everything was normal. Just a handful of allies turned up. $\mathrm{He}$ was living in a bubble, unaware of the scale of the storm gathering around him. This was despite his former counter-part of Zambia, Kenneth Kaunda who had been sent to Harare to try convince Mugabe to step down in a "dignified exit". Kaunda used the presidential jet. However, by afternoon, it had dawned on Mugabe that he had run out of options. He was facing the humiliation of impeachment. He had lost the people. Now he had also lost the military and the party. $\mathrm{He}$ signed his resignation letter as parliament went through the motions of the impeachment process. The letter was delivered and the Speaker of Parliament, Jacob Mudenda, read it out to a jubilant house. Daily News, November 22, 2017 carried a story titled 'Croc rises as Mugabe falls'. On the same page (2), the newspaper covered a photograph with a caption "Ecstatic Zanu PF legislators Oppah Muchinguri-Kashiri (standing) and Obert Mpofu embrace upon hearing news that Robert Mugabe had resigned as president during a joint parliamentary sitting 
in Harare yesterday (21 November 2017)". The curtain finally came down on President Robert Mugabe's 37-year rule, as he resigned with immediate effect, triggering massive celebrations across the country. Part of Mugabe's resignation read as follows:

Following a verbal communication with the Speakers of Parliament, Jacob Mandela at 13:53 hours on November 21, 2017 intimating my intention to resign as the president of the republic of Zimbabwe, I, President Robert Gabriel Mugabe, in terms of section 96 (1) of the constitution of Zimbabwe hereby tender my resignation as the President of the Republic of Zimbabwe with immediate effect. My decision to resign is voluntary on my part and arises from my concern for the welfare of the people of Zimbabwe and my desire to ensure a smooth, peaceful nonviolent transfer of power that underpins national security, peace and stability. Kindly give public notice of my decision as soon as possible.

Another story in Daily News of same day was titled: 'Mugabe Falls on his own sword' (p.3). This article argues that Mugabe's failure to decisively deal with the ZANU PF succession and the manner in which he tried to resolve it lately-by using his wife Grace as foil-became his downfall. The resignation of Mugabe was an ignominious end to his long and controversial career. He could have avoided this humiliation if he had heeded the signs and appreciated the reality that he could not go on forever. In fact, he could have clearly groomed a successor and handed power many years ago. But it seems Mugabe was too stubborn to let go. His rather 'tragic' end marked the dawn of a new era (The Herald, 22 November 2017). His tragic flaw or downfall was the 'illusion'that the party still supported him; yet it was not. As argued earlier, Mugabe's wife, Grace, was also a factor to his demise. That Grace Mugabe's role was a trigger of the events that led to Mugabe's demise was publicly confirmed by Patrick Chinamasa the Finance ministerand close ally of Mnangagwa at an event in South Africa.

\section{The New Political Dispensation - the Rise of Mnangagwa}

There have been important changes to the security sector and government, demonstrating yet another chapter of major developments in Zimbabwe. In terms of personnel these changes demonstrate efforts by the administration at reconstituting and re-configuring the state and its key structures after taking power in dramatic circumstances in November 2017. President Mnangagwa is clearing out residual elements of the old regime and setting up a new team that is amenable to his agenda. Having come to power on the back of the military, he is well aware of its power and the threat it poses, hence the need to reconfigure it. The security sector under the Mnangagwa administration will therefore be different from the one that served Mugabe.

Although Lacoste faction is now in charge, they also know that the enemy is still alive, so they cannot afford to be complacent. This is why they have to consolidate their power and hold over the state. The military played a key role in this process, which is why leading members occupy key positions within the state. The appointment of retired General Chiwenga as Vice President was not surprising as it was always believed he would deputize Mnangagwa in the event of a Lacoste victory in the succession race. Chiwenga was not an impartial bystander in ZANU PF's succession war. As one senior military officer asserted, 'Chiwenga's plan is to succeed ED (Mnangagwa) after ED succeeds Mugabe. When ED is President, Chiwenga will his Vice President. There is an alliance between the two' [15]. It can be argued that Chiwenga will be eying the top office after Mnangagwa; especially if they win 2018 elections. However, the appointment of Chiwenga to take charge of the Ministry of Defence shows the military man's desire to control and influence over his main source of power. Others will argue that having Retired General Chiwenga maintaining a role in the military through the defence ministry ensures the current government is insulated against insurrection. In other words, the current government is aware that a dangerous precedent was created in November 2017, when the military intervened to set off the chain of events that led to Mugabe's downfall. They cannot allow a new set of men in charge while they are confined to the civilian structure. It is better therefore to have a military man, whom the soldiers understand, are loyal to and perhaps fear, in charge of the political authority, which is the defence ministry. In this way, the view is that the government is creating a coup-proof structure.

However, when President Mnangagwa swore in the new cabinet, the new cabinet failed to inspire the nation as it was viewed as Mugabe's deadwood ministers who were retained, serve for few retired security chiefs. It had been hoped that he would appoint members of the opposition to his cabinet to form a transitional government until elections 2018 but this did not happen.

This article argues that the media (particularly the private press) played a role in informing citizens about possibility of unity government. In this regard, concerns have been raised, especially in terms of the inadequate role played by the media in informing citizens on the development and the rise in speculation, sensationally, rumors and unethical practices that characterized the coverage of events.

Daily News, 24 and 30 November, 2017 published stories with the following headlines respectively: 'Zanu PF unity govt... as politburo gives Mnangagwa full backing and 'Tsvangirai in GNU dilemma... MDC divided over unity govt'. The newspaper quoted an unnamed senior Zanu PF official saying:

... ED got the backing of the politburo on the need to form a government that includes opposition figures. Both him and the party are aware of the need to heal previous rifts, unite the people and resuscitate the economy. Part of uniting people is having an inclusive government based on trust and unity..

The Daily News also reported that MDC leader Morgan Tsvangirai was engaged in behind-the scenes- discussions with President Mnangagwa over the formation of an inclusive cabinet that could help unite the nation's deeply-divided citizens. However, even if MDC-T members were not divided over the issue of the possibility of another government of national unity (after 2009-2013 GNU), war veterans who had filled strategic party and government positions may not have been comfortable with the move. Many of Mnangagwa allies had to be rewarded in many ways.

It is important to note that the new dispensation is characterized by militarization of government, which was necessitated by the movement of top generals from the security sector to civilian government. If this view is correct, it is certainly not a new one. Military historians have $\log$ chronicled and explained the phenomenon of militarization of the state and government since even before independence. In 2009 paper on security sector reform, Knox Chitiyo explained how these process of politicization of the military and militarization of the state have taken place in phases since independence, Magaisa [14] argues that militarization is the culmination of a process that has been going on for quite some time and will probably continue well into the future. Part of this is a result of Zimbabwe's specific history in which the political parties that became the governing authorities after independence had armed wings which had their own command structures which were heavily politicized and never really shed off these characteristics after independence. 
According to Magaisa, the military movements are a reward for the role in dislodging Mugabe in November 2017. It was the military that rescued Mnangagwa bid for the presidency after he had been sacked by Mugabe on 6 November 2017. On 15 November, the military moved in to control the state and this set off a chain of events that led to Mugabe's resignation and the consequent installation of Mnangagwa as his replacement; as this article has explained in detail earlier. The other view is that the generals who have joined government have not been moved. They have moved because that is what they want. This article argues that the military is capturing both the government and the party. It will also increase fears that the election in 2018 may become compromised by military involvement. A clear example is that of Major General Engelbert Rugeje who was promoted to Lieutenant General upon retirement from the military.

Consequently he was appointed ZANU PF's political commission at the December 2017 Extraordinary Congress. The political commissar is the organizer and mobiliser of the party [5]. It suggests that the election campaign will carry a heavy military complexion. It is important to note what happened in 2008 and 2013 elections. Tendi [15] argues that an extensive network of retired military officers helped mobilize support for Mugabe in the 2013 election. These officers, many of whom were ex-ZANLA and retired from the military specifically for the 2013 campaign, were deployed in the Zimbabwean countryside as political commissars. The use of retired soldiers as political commissars was a demonstration of ZANU PF's recourse to tried and tested wartime tactics of political mobilization and control, as ZANLA political commissars operating in the countryside are credited for ensuring ZANU PF's strong victory in the 1980 independence election [15]. However, contrary to general fears, the strong presence of the military does not necessarily mean it will be a violent campaign on the contrary; there is no incentive for the administration to the use of violence since they are well aware that it undermines the credibility and legitimacy of elections. They are well aware too that after the events of November (the military coup), the run up to 2018 elections will be closely watched by the rent of the world. However, it is disturbing to note that there are already many cases where the military are intimidating the electorate by asking them to provide serial numbers of registration slips. If this speculation becomes reality then the 2008 violence might be relived. It is sad that Chief Fortunate Charumbira, president of chiefs does not hide his allegiance to ZANU PF and openly tells the nation that chiefs alongside all traditional leaders will support ZANU PF in the 2018 election, contrary to the Zimbabwean constitution which states that they should be impartial or apolitical.

\section{Conclusion}

This article concludes that the downfall of Robert Mugabe in November 2017 was the most dramatic event for most Zimbabweans and many who follow the politics of the Southern African country. After leading the country for 37 years and planning to go for another term (at the age of 94), and having been thwarted several times in their efforts to vote him out of power, many Zimbabweans had become frustrated, disillusioned and pessimistic in recent years. Some had long resigned to their fate, believing Mugabe was destined to rule for life.

However, November 2017 marked an epic turn of fortunes for Mugabe, as the once loyal military launched a dramatic operation (dubbed Operation Restore Legacy) which effectively pushed him out of power. While the military took care to dress up their operation in legal apparel, beyond veil, it was to all intents and purposes, a military revolt or coup which no one had seen coming. A legal specialist, argues that under the Constitution, only the President and Commander-inchief of the defense forces has the power to deploy the defense forces within Zimbabwe. Mugabe had no role in the deployment of the defense forces in November. It was clear that he had lost command of the defense forces and his fate was no longer in his hands. The dramatic circumstances of the collapse of Mugabe's rule captured the world's attention. After dominating Zimbabwean politics for decades, it was ironic that in the end he succumbed so feebly to the crafty machinations engineered by some of his most trusted allies; he will forever feel betrayed by his comrades, but he must shoulder a large amount of responsibility for his own demise. Mugabe's betrayal by Mnangagwa can be likened to Julius Caesar who was betrayed by Brutus. Mugabe had all the time in the world and all the warnings to prepare a dignified exit for himself. But Mugabe had never shown any intention to retire because the ZANU PF party and the state-controlled media had fooled him that he was still needed by the party.

Mugabe's humiliating exit is arguably a lesson to the folly stubbornness. This article has earlier pointed out his stubborn streak which was evident during his last days in office. Even as his old military and political allies applied pressure upon him, Mugabe refused to bend. His anti-climactic "Asante Sana" speech on 19 November, 2017, will be remembered forever. In the end, Mugabe fell on his sword. During his time as president, he relied heavily on the military in order to thwart political opponents. The military were happy to do his bidding as long as their interests were protected. However, in the last two years, Grace Mugabe took center-stage and began to ruffle feathers, threatening the interests of the military. The relationship between Mugabe and his allies in the military and among war veterans ruptured. Mugabe forgot that his source of power lay in the military and believed the thousands who were forced to come to his rallies were genuine supporters. It was Grace's relentless attacks which raised the political temperatures. According to Magaisa [6], Mugabe had two protagonists vying to succeed him. One was his wife, Grace and the other, was his longtime lieutenant, Emmerson Mnangagwa. He chose his wife and this precipitated a revolt by his lieutenant who had the advantage of backing from the military who usurped power from him through a coup. The military gave power to Mnangagwa. This article concludes that a section of the Military Intelligence (MI) leadership backed Mnangagwa in the succession infighting, placed Mugabe and G40 under surveillance and then engineered the November 2017 military takeover.

This article also concludes that one of the achievements in the new political dispensation in Zimbabwe is that of police who lost their authority to military. In recent years, police had become a real menace and were so unpopular that when the military took over and suspended police operations in November, people celebrated. Police harassment and corruption on the streets and every sphere of Zimbabwe had become a thorny issue. Consequently, this resulted in the firing of Commissioner General August Chihuri and many senior assistant commissioners. For the serving police, it might take long for them to regain self-esteem and reorientation as the fear of military 'eyes' keeping surveillance still haunts them.

As pointed out earlier, both local and foreign media have been heavily involved in the coverage of the ouster of Mugabe and the new political dispensation. This article concludes that state-controlled media, which is supposed to be public media had challenges in representation of succession conflict in the ruling ZANU PF. From 2015 when new factions emerged in ZANU PF, state-owned media depicted G40 faction positively - unapologetically behind the First Family then, while exposing Team Lacoste which was in support of Emmerson 
Citation: Mungwari T (2018) Media Framing of Zanu Pf Internal Succession Struggles: Mnangagwa and the Military Factor. J Mass Communicat Journalism 8: 369. doi: 10.4172/2165-7912.1000369

Page 11 of 11

Mnangagwa. From the time military took over, some ZANU PF officials were still in denial as evidenced by the state-owned daily, The Herald coverage of events from Monday 13 to Wednesday 15 November 2017. Reporters were in a crisis on how to cover events as they obtained. On Monday 13 November, ZDF Commander General Constantine Chiwenga addressed the nation at a press conference while flanked by many other generals but the state media including The Herald did not cover the event. This was deliberate omission because the media was still in intransigent support of Mugabe and the First Family as well as G40. Instead, The Herald and other electronic state-controlled ZBCTV and radio stations extensively broadcast ZANU PF Youth Secretary, Kudzanai Chipanga's address. Such representation was in defiance of the military that had 'stepped in' the political arena. The crisis was pronounced on Wednesday, 15 November when The Herald published a story with a headline: 'Zanu PF unfazed by Chiwenga' which was juxtaposed by yet another story titled: 'we'll defend President with our lives: Youths'. Chipanga told journalists at a press conference on 14 November that the youth would stand by President Mugabe in the face of any threat to his position as the constitutionally elected leader of Zimbabwe.

This press conference was to counter the one that had been addressed by General Chiwenga on the previous day. These stories incensed the military who had taken over levers of power and consequently ordered printing of another edition of The Herald. This was unprecedented. The Herald Special Edition carried a story with a headline: 'No military takeover: ZDF' and two the stories with titles: 'In defence of the nation's founding values, gains of independence' and ' $\mathrm{We}$ are targeting the criminals around the President'. This article concludes that the military had demonstrated total capture of state institutions, and the public broadcast and Zimpapers were some of them. It should be pointed out that The Herald then covered General Chiwenga's press conference as well as Major General Sibusisiwe Busi Moyo's address of the nation on ZBCTV on the morning of 15 November, 2017. The military was at pains to inform the nation and the world at large that it was not a military coup or military takeover of Government but that their action was meant to address the political, social and economic situation that could have ended in violent conflict. The other emphasis was that the military was 'targeting the criminals around the President'.
From 15 November 2017, all state media, both print and electronic tore the line of the military or Team Lacoste now in charge of government.

However, the private press maintained their middle of the road approach in which their reportage was arguably neutral as they represented events as they unfolded without showing any support or favour to any ZANU PF faction. Nonetheless, both state-controlled and privately owned media should adopt peace journalism so as to achieve political conflict resolution, especially after President Mnanganwa's acceptance speech which talked of letting bygones be bygones.

\section{References}

1. Mungwari T (2017) Framing of ZANU PF purges and Succession Dynamics. Int Jour Inn Res 3:766-782.

2. International Crisis Group (2016) Zimbabwe: Stranded in Stasis. Crisis Group Africa Briefing.

3. RAU (2017) Zimbabwe since the elections in July 2013: The View from 2017. Research \& Advocacy Unit.

4. Chitiyo K (2009) The case for security sector reform in Zimbabwe. Occasional Paper, RUSI.

5. Mungwari T (2017) Representation of political conflict in the Zimbabwean press: The case of The Herald, The Sunday Mail, Daily News \& The Standard, 1999-2016. Uni S Afr.

6. Magaisa AT (2017) Big Saturday Read: The month of long knives?

7. Magaisa AT (2017) BSR Special: The end of an era

8. Mandaza I (2016) The Political Economy of the state in Zimbabwe: The rise and fall of the Securocrat State. Zimbabwe Independent.

9. Braton M (2014) Power Politics in Zimbabwe. Wiley online library.

10. Southall R (2013) Liberation Movements in Power: Party \& State in Southern Africa. James Currey, UK; UKZN Press.

11. Rupiya M (2011) The Military Factor in Zimbabwe's Political and Electora Affairs. Crisis in Zimbabwe Coalition.

12. Matyszak D (2011) Zimbabwe's Security Sector - Who Calls the Shots? RAU.

13. Magaisa AT (2017) BSR: Implications of changes to the security sector.

14. Magaisa AT (2017) Big Saturday Read: The downfall of Robert Mugabe.

15. Tendi BM (2016) State Intelligence \& the Politics of Zimbabwe's Presidential Succession. African Affairs, Oxford University Press. R Afr Soc. 